InImag9/2018

\author{
Incursiuni în imaginar 9. Poxemica în literatură/ \\ Incursions into the Imaginary 9. Proxemics in literature
}

\title{
Cosmin PORUMB-GHIURCO, A Touristic Approach of a Literary and Geographical Space: Transylvania
}

\begin{abstract}
StudyinqTransylvania as a literary and qeoqraphical space or as a qeo-literary space also involves an approach from the field of cultural tourism studies. As a aeographical and historical reqion of Romania, Transylvania is one of the most notorious tourist destinations in the world. Its literary notoriety plays an important role in attracting tourists and building th ereqion's touristic imaqe(ry) often considered as a social and cultural construct due to its WestEast antithesis. In this paper, we study the interconnectivity between works of fiction as created cultural forms and their impact on tourism industry and consumer society. The tourist is thus perceived both as a consumer and homo ludens in the postmodern contemporary context. Therefore, the focus is on the acknowledqement that fictional is employed in the non-fictional framework so as to produce anthropic tourist attractions. In the present study, we took into account the fictional profile of Transylvania as a framework for the phenomenon of escapism, which involves the traveller-reader binomial. Thus, studying the ways and means through which the illusion of the fictional is nowadays perpetuated into these places and used to attract avid readers and cinephiles is one of the main research targets.
\end{abstract}

Keywords: Transylvania; geoliteraryspace; touristimage(ry); traveller-reader binomial; chronotope

\section{References:}

Bakhtin, M. M. (1981). The Dialogic Imagination. Austin: University of Texas Press.

Benjamin, W. (1968). Illuminations. New York: Schocken Books.

Boner, C. (1865). Transylvania: Its Products and its People. London: Longmans, Green, Reader and Dyer.

Ciangă, N. (2007). România. Geografia turismului (Romania. The Geography of Tourism). ClujNapoca: Editura Presa Universitară Clujeană.

Curtis, A. (2008). Literature andTourism. An HonorsThesis (HONRS 499). Indiana: Ball State University.

De Certeau, M. (1984).The Practice of Everyday Life, Berkley. California: University of California Press.

Douglas, N. et al. (ed.). (2001). Special Interest Tourism. Milton: John Wiley and Sons Australia Ltd.

Goldsworthy, V. Inventing Ruritania - The Imperialism of the Imagination, London: Hurst \& Co.

Herbert, D. (2001). Literary places, tourism and the heritage experience. In Annals of Tourism Research, Vol. 28, No 2, 312-333.

Hoppen, A. et al. (2014). Literary Tourism: Opportunities and Challenges for the Marketing and Branding of Destinations? In: Journal of Destination Marketing and Management.

Jafari, J. (2000). Encyclopedia of Tourism. London: Routledge.

Lefebvre, H. (1991). The Production of Space. Oxford: Blackwell.

Pop, P. Gr. (1997). România. Cadru geografic unitar (Romania. Unitary Geographical Framework). In Istoria României. Transilvania, vol. I, Edit. Societății Cultural-Știinţifice "George Barițiu”, Cluj-Napoca, pp. 5-62.

Porumb-Ghiurco, C.-G. (2010). Castelele și conacele din județul Sălaj (reședințele nobiliare): componentă cultural-turistică reprezentativă (Castels and Manors from the Sălaj County (Aristocratic Residences): Cultural and Tourist Representative Component), graduation thesis, Faculty of Geography, "Babeș-Bolyai" University, Cluj-Napoca.

Porumb-Ghiurco, C.-G. (2012). Municipiul Cluj-Napoca: potențială capitală culturală europeană în anul 2021. Rolul turismului în acest demers (Cluj-Napoca: The Potential European Capital of Culture in theYear 2021. The Role of theTourism in this Context), dissertation thesis, Faculty of Geography, "Babeș-Bolyai" University, Cluj-Napoca. 
Porumb-Ghiurco, C.-G. (2014). The Tourist Image of Transylvania: from Fiction to Reality. In Thematic Tourism in a Global Environment: Advantages, Challenges and Future Developments, Conference Proceedings (799-811), BITCO, College of Tourism, Belgrade.

Robinson, M., Andersen, H.C. (eds). (2002). Literature and Tourism: Reading and Writing Tourism Texts. London: Continuum.

Reijnders, S. (2011). Places of the Imagination: Media, Tourism, Culture. Farnham: Ashgate.

Selwyn, Tom, ed. (1996). The Tourist Image: Myths and myth making in tourism. Chichester: Wiley.

Smith, Y. (2012). Literary Tourism as a Developing Genre: South Africa's Potential. Pretoria: University of Pretoria Magister Paper.

Stoker, B. (1998). Dracula. Oxford: Oxford University Press.

Watson, N. J. (ed). (2009). Literary Tourism and Nineteenth Century Culture. Basingstoke: Palgrave Macmillan.

\section{Cite This Item}

\section{Copy Citation}

\section{APA}

Ghiurco-Porumb, C. (2018). A Touristic Approach of a Literary and Geographical Space:

Transylvania. Incursiuni în imaginar, (9), 29-45. DOI:10.29302/InImag.2018.9.2

\section{MLA}

Ghiurco-Porumb, Cosmin. "A Touristic Approach of a Literary and Geographical Space:

Transylvania”. Incursiuni în imaginar, no. 9, 2018, pp. 29-45. www.inimag.uab.ro.

DOI:10.29302/InImag.2018.9.2

\section{ROMANIAN ACADEMY DEMANDS}

Ghiurco-Porumb, Cosmin, A Touristic Approach of a Literary and Geographical Space: Transylvania, în „Incursiuni în imaginar”. Proxemica în literatură, nr. 9, 2018, pp. 29-45. DOI:10.29302/InImag.2018.9.2 